\title{
7- Yabancı dil öğrenme yönetim sistemi tasarımı önerisi
}

\section{Kerim SARIGÜL}

APA: Sarı̈ül, K. (2021). Yabancı dil öğrenme yönetim sistemi tasarımı önerisi. RumeliDE Dil ve Edebiyat Araştırmaları Dergisi, (Ö10), 127-142. DOI: 10.29000/rumelide.1009047.

$\ddot{\mathbf{O} z}$

Günümüzde yabancı dil öğrenmek ve öğrenilen yabancı dili kullanmak en önemli becerilerden biridir. $\mathrm{Bu}$ beceriye sahip olmak isteyenler gerek yüz yüze ve uzaktan gerekse art zamanlı ve eş zamanlı derslerle bu beceriyi kazanma, var olan becerilerini geliştirme çabası içindedirler. Teknolojinin bugün geldiği nokta düşünüldüğünde yabancı dil öğretimi/öğrenimi hangi yolla gerçekleşirse gerçekleşsin bu sürecin en önemli unsurlarından biri zenginleştirilmiş, etkileşimli dijital materyallerdir ve bu materyallerin sunulduğu dijital platformlardır. Yabancı dil öğretimi/öğrenimi sürecinde içerik hazırlamak, içeriği sunmak ve öğrenim sürecini değerlendirmek amacıyla kullanılabilecek çevrim içi ve çevrim dışı çeşitli araçlar mevcuttur. İnternetin yaygınlaşması ve web teknolojilerindeki gelişmeler web 2.0 araçlarının ortaya çıkmasını ve bunların eğitimde, dil öğretiminde aktif bir şekilde kullanılmasını sağlamıştır. Bugün eğitim ve öğretimde kullanılabilecek binlerce web 2.0 aracı bulunmaktadır. Web 2.0 araçları incelendiğinde çoğunun tek bir alana, tek bir beceriye veya tek bir içerik türüne yönelik araçlar olduğu görülmektedir. Örneğin en yaygın kullanılan süreç değerlendirme araçlarından biri olan "EdPuzzle" sadece videolarla çalışmaktadır, "Canva" daha çok görsel içerikler hazırlamak için uygundur, "Youtube"da ise sadece video içerikleri sunulabilmektedir. Bunlar ve bunlara benzer web 2.0 araçlarında elbette yabancı dil öğretiminde kullanılabilecek pek çok yenilikçi özellik mevcuttur ancak tek başlarına öğretim sürecini ayakta tutacak, öğretmen ve öğrencilerin dil öğretim/öğrenim sürecinde ihtiyaç duydukları dijital imkanları sunacak özelliklere sahip değillerdir. Ayrıca web 2.0 araçlarının çoğunun ayrı üyelik istemesi öğretim/öğrenim sürecini zorlayabilmektedir. Çeşitli web 2.o özelliklerine sahip Öğrenme Yönetim Sistemleri (ÖYS) mevcuttur ancak bunlar da yabancı dil öğretiminin ihtiyaçlarına; özellikle de okuma, dinleme, yazma, konuşma becerilerinin geliştirilmesine, kelime ve dil bilgisi öğretimine tam olarak hizmet edememektedir. Bunlar ve bunlara benzer çeşitli eksiklikler yabancı dil öğretiminde ve öğreniminde kullanılabilecek özelliklere sahip bir "Yabancı Dil Öğrenme Yönetim Sistemi"nin (bundan sonra YDÖYS) geliştirilmesini gerekli kılmaktadır. Bu amaç doğrultusunda "Yönetimsel ve Yapısal Özellikler", "Etkinlik Türleri (Öğretim ve Değerlendirme)”, "Raporlama - Suralama”, “Oyunlaştırma”, "Yapay Zekâ Rehberliği”, "Bireyselleştirilmiş Kütüphane” olmak üzere 6 bileşenden oluşan YDÖYS ortaya konmuş, her bir bileşende yer alması gereken özellikler listelenmiştir. Böyle bir sistem geliştirildiği takdirde, tüm dillerin yabancı dil olarak öğretimine hizmet edebileceği gibi Türkçenin yabancı dil olarak öğretiminde de etkin bir şekilde kullanılabilecektir.

Anahtar kelimeler: Yabancı dil öğrenimi, Web 2.0 araçları, Yabancı dil öğrenme yönetim sistemi

Dr. Öğr. Gör., Gazi Üniversitesi, TÖMER (Ankara, Türkiye), sarigulkerim@gmail.com, ORCID ID: oooo-ooo2-3337-8910 [Araştırma makalesi, Makale kayıt tarihi: 24.09.2021-kabul tarihi: 20.10.2021; DOI: 10.2900o/rumelide.1009047]

Adres | Address

RumeliDE Dil ve Edebiyat Araştırmaları Dergisi Osmanağa Mahallesi, Mürver Çiçeği Sokak, No:14/8 Kadıköy - ISTANBUL / TÜRKIYE 34714 e-posta: editor@rumelide.com tel: +90 $5057958124,+902167730616$

RumeliDE Journal of Language and Literature Studies Osmanağa Mahallesi, Mürver Çiçeği Sokak, No:14/8

Kadıköy - ISTANBUL / TURKEY 34714

e-mail: editor@rumelide.com,

phone: +90 505 7958124, +90 2167730616 


\title{
Design proposal for a foreign language learning management system
}

\begin{abstract}
Today, learning a foreign language and using the learned foreign language is one of the most important skills. Those who want to have this skill are in an effort to acquire this skill and improve their existing skills through face-to-face and distance courses as well as synchronous and asynchronous courses. Considering the point that technology has reached today, one of the most important elements of this process is enriched, interactive digital materials and digital platforms where these materials are presented, regardless of the way foreign language teaching/learning takes place. There are various online and offline tools that can be used to prepare content, present the content and evaluate the learning process in the foreign language teaching/learning process. The spread of the Internet and the developments in web technologies have enabled the emergence of web 2.0 tools and their active use in education and language teaching. Today, there are thousands of web 2.0 tools that can be used in education and training. When Web 2.0 tools are examined, it is seen that most of them are tools for a single area, a single skill, or a single content type. For example, "EdPuzzle", one of the most widely used processes evaluation tools, works only with videos, "Canva" is more suitable for preparing visual content, while only video content can be presented on "Youtube". Of course, these and similar web 2.0 tools have many innovative features that can be used in foreign language teaching, but they do not have the features to sustain the teaching process and provide the digital opportunities that teachers and students need in the language teaching/learning process. In addition, the fact that most of the web 2.0 tools require separate membership can force the teaching/learning process. Although there are Learning Management Systems (LMS) with various web 2.o features, they cannot meet the needs of foreign language teaching; In particular, they cannot fully serve the development of reading, listening, writing, speaking skills, and teaching vocabulary and grammar. These and similar deficiencies require the development of a "Foreign Language Learning Management System" (FLLMS) with features that can be used in foreign language teaching and learning. For this purpose, YÖYS consisting of 6 components ("Administrative and Structural Features", "Types of Activity", "Reporting - Sequencing", "Gamification", "Artificial Intelligence Guidance", "Individualized Library") has been put forward and the features that should be included in each component are listed. If such a system is developed, it will not only serve to teach all languages as a foreign language, but it will also be used effectively in teaching Turkish as a foreign language.
\end{abstract}

Keywords: Foreign language learning, Web 2.0 tools, Foreign language learning management system

\section{Giriş}

Bugün dünyada milyarlarca kişi iş, eğitim, seyahat, araştırma, evlilik, göç vb. sebeplerle yabancı dil öğrenmektedir. Tüm bu sebepler aslında bize yabancı dil öğreniminin içinde bulunduğumuz çağda meraktan çıkıp zorunluluk haline geldiğini göstermektedir. Hâl böyle olunca yabancı dil öğrenmek isteyenlerin sayısının her geçen gün arttığını, dil öğrenmeye başlama yaşının ise düştüğünü söylemek yanlış olmaz. Avrupa İstatistik Ofisi (2016) tarafından yapılan bir araştırmada gençlerin yetişkinlere göre daha fazla yabancı dil bildiği ortaya konmuştur (Şekil 1). Ayrıca ilk basımından 20 yll sonra revize edilen ve 2020 yılında yeni açıklamaları ile yayımlanan Diller İçin Avrupa Ortak Öneriler Çerçevesine (CEFR, 2020: 13) genç öğrencilere (young learners) yönelik yeterlik tanımlamalarının eklenmesi ve ayrıntılandırılması da bu görüşü destekler niteliktedir.

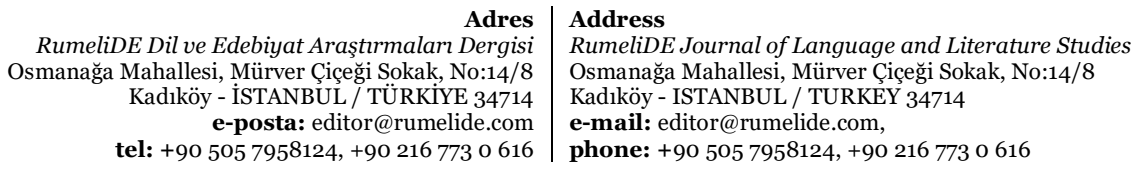




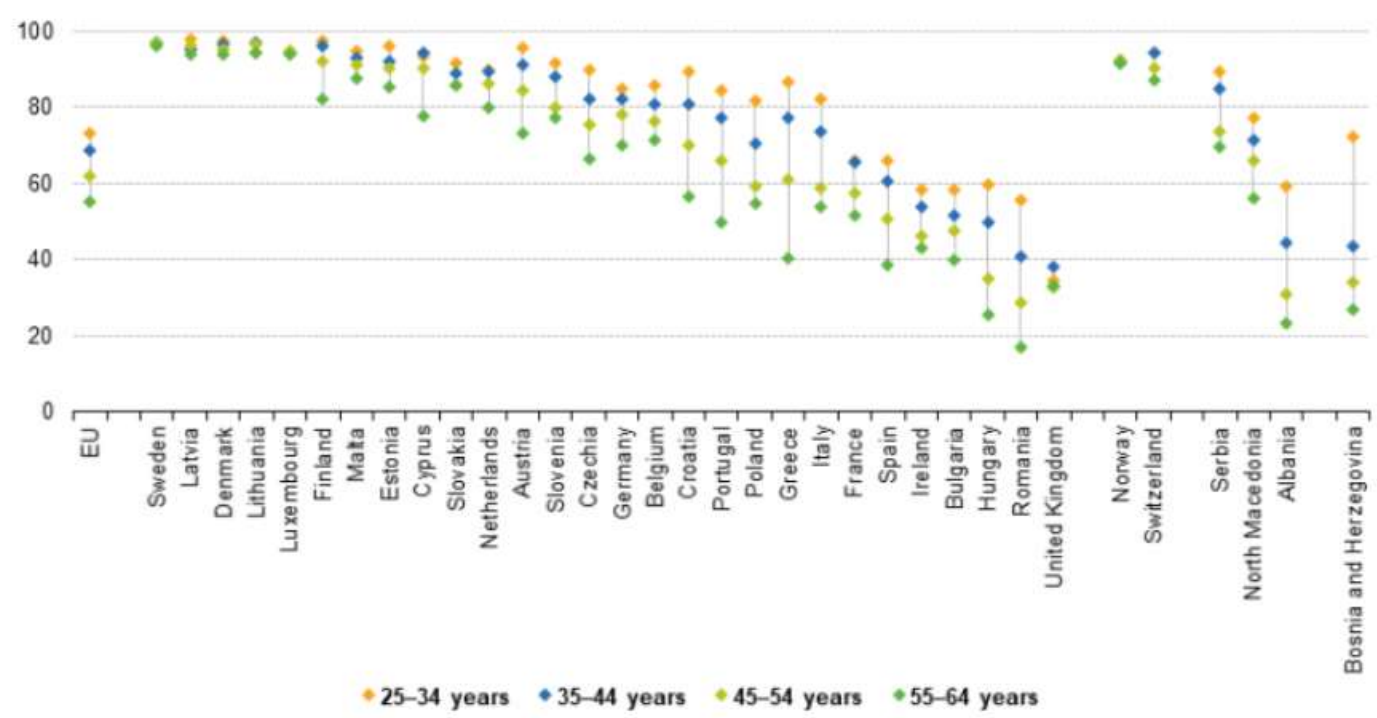

(') Ranked on the share for all persons aged 25-64. Turkey. not available.

Şekil 1: Avrupa'da bir veya daha fazla yabancı dil bildiğini belirten kişilerin yaş aralığı (Avrupa İstatistik Ofisi, 2016)

Dünyanın her geçen gün daha da dijitalleştiği ve küreselleştiği düşünüldüğünde yabancı dil bilme oranının $\mathrm{AB}$ ülkelerinde olduğu gibi tüm dünyada her geçen gün daha da artacağı ifade edilebilir. 75 ülke verilerine dayanan PISA 2018 raporu, öğrencilerin \%95'inden fazlasının ya birden fazla dil konuştuğunu ya da en az bir yabancı dil öğrenmekte olduğunu göstermektedir (OECD, PISA 2018 Veritabanı). Bu veriler bize yabancı dil öğretme ve öğrenme konusuna daha fazla eğilmemiz gerektiğini ortaya koymaktadır.

Teknolojinin bugün geldiği nokta düşünüldüğünde yabancı dil öğretimi/öğrenimi hangi yolla gerçekleşirse gerçekleşsin bu sürecin en önemli unsurlarından biri zenginleştirilmiş, etkileşimli dijital materyallerdir ve bu materyallerin sunulduğu dijital platformlardır. Bugün yabancı dil öğreten ve öğrenenlerin okuma, dinleme, yazma, konuşma becerilerini geliştirmede kullanabilecekleri zengin içerikler ve çeşitli araçlar (z-kitaplar, dijital oyunlar, konuşma botları, web 2.0 araçları vb.) mevcuttur. Son yıllarda yabancı dil öğretiminde ve Türkçenin yabancı dil olarak öğretiminde teknoloji kullanımına yönelik araştırmaların arttı̆̆ı, özellikle de yabancı dil öğretiminde ve öğreniminde bilgisayar kullanımı ve teknoloji entegrasyonu (Sahin, 2010; Kazikoğlu, 2013; Özcan ve Altıparmak, 2016; Zengin ve Aksu, 2017; Yaman ve Bozdemir, 2010; Kazazoğlu, 2014; Birinci, 2020); web 2.0 araçları, sosyal medya, bloglar, ders dışı öğrenme ortamları (Bozavlı, 2017; Ustabulut ve Keskin, 2020; Sevim ve Kara 2019; Taylan, 2018; Sarı, 2018; Aslan, 2018; Göker ve İnce, 2019; Moralı, 2018; İnal ve Arslanbaş, 2021; Sarıgül, 2021; Karatay, Karabuğa ve İpek, 2018; Demiral ve Yavuz, 2016), dijital hikâyeler (Kaya ve Tekiner Tolu, 2017; Çokyaman ve Çelebi 2021; Türker, 2019), e-portfolyo (Erice ve Ertaş, 2011), sanal sınıflar (Bozavlı, 2017), robot öğretmenler (Aslan, 2014); öğretmen ve öğrenci öz yeterlikleri, algıları ve görüşleri (Bozna, 2019; Geçgel ve Peker, 2020; İnal, 2020) gibi konulara yoğunlaşıldı̆̆ı, Web 2.0 araçlarının eğitimin tüm alanlarında olduğu gibi yabancı dil öğretiminde de yaygın olarak kullanıldığı görülmektedir. Yabancı dil öğretiminde kullanılabilecek Web 2.0 araçları incelendiğginde çoğunun tek bir alana, tek bir beceriye veya tek bir içerik türüne yönelik araçlar olduğu görülecektir. Örneğin en yaygın kullanılan süreç değerlendirme araçlarından biri olan "EdPuzzle" sadece videolarla

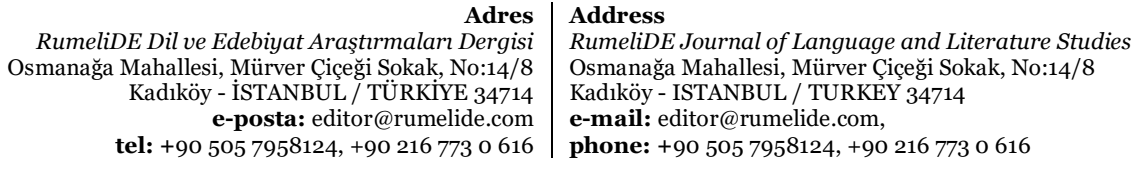


çalışmaktadır, "Canva" daha çok görsel içerikler hazırlamak için uygundur, "Youtube"da ise sadece video içerikler sunulabilmektedir. Bunlar ve bunlara benzer web 2.0 araçları yabancı dil öğretiminde kullanılabilecek çeşitli özelliklere sahip olmakla birlikte tek başlarına öğretim sürecini ayakta tutacak, öğretmen ve öğrencilerin dil öğretim/öğrenim sürecinde ihtiyaç duydukları dijital imkânları sunacak özelliklere sahip değillerdir. Bir başka dezavantajlarından biri de bu tür araçların çoğunun ayrı üyelik gerektirmesidir.

\section{Öğrenme yönetim sistemleri (ÖYS)}

Dünyada okul, kurs, ders, öğrenci, öğretmen, materyal, sınav gibi eğitim ve öğretim bileşenlerinin bir kısmını veya tamamını yönetmek amacıyla geliştirilmiş olan öğrenme yönetim sistemleri mevcuttur. İlk olarak 1920'lerde Sidney L. Pressey tarafından geliştirilen öğretim makinesi, çeşitli pratik alıştırmalar ve çoktan seçmeli sorulardan oluşmaktaydı (Sidney L. Pressey, t.y.). Aradan geçen yüz yıllık dönemde yüzlerce öğrenme yönetim sistemi geliştirildi ve geliştirilmeye de devam etmektedir. Teknolojinin gelişmesi ile birlikte öğrenme yönetim sistemlerinin yapısı ve özelliklerinin de değişmesi olağandır. Bugün gelinen noktada web teknolojilerinin, yapay zekânın, makine öğrenmesinin sunduğu imkânların bu sistemlere entegre edilmesi beklenmektedir. Çevrim içi öğrenmenin yaygınlaştı̆̆ı, kendi kendine öğrenmenin arttığı bu dönemde öğrenme yönetim sistemleri daha da büyük önem kazanmaktadır. "2019 Yılı Çevrimiçi Ĕ̆itim Eğilimleri Raporu” (Best Colleges, 2019) katılımcıların neredeyse \%50'sinin iş, aile ve diğer bazı sebeplerden dolayı çevrimiçi kursları tercih ettiğini göstermektedir. Bu da gelecek yıllarda eğitim ve öğretimin dijital yükünü öğrenme yönetim sistemlerinin üstleneceğini ortaya koymaktadır. Eğitim ve öğretim sürecini yönetmek amacıyla kullanılan onlarca öğrenme yönetim sistemi geliştirilmiştir ve bunlardan bazıları yaygın bir şekilde kullanılmaktadır. Phil Hill (2017) tarafından hazırlanan, ABD ve Kanada’yı içeren araştırma raporuna göre Yüksek Öğrenim Kurumlarının \%87'si "Blackboard", "Canvas", "Moodle" veya "D2L Brightspace" kullanmaktadır. Bu oran aynı zamanda öğrencilerin \%91’ine tekabül etmektedir.

\begin{tabular}{|l|r|r||r|}
\hline LMS Solution & $\begin{array}{l}\text { Fall } 2017 \text { by } \\
\text { Institutions }\end{array}$ & $\begin{array}{l}\text { Fall } 2016 \text { by } \\
\text { Institutions }\end{array}$ & $\begin{array}{l}\text { Fall } 2017 \text { by } \\
\text { Enrollments }\end{array}$ \\
\hline Blackboard Learn & $28 \%$ & $31 \%$ & $37 \%$ \\
\hline Instructure Canvas & $21 \%$ & $17 \%$ & $27 \%$ \\
\hline D2L Brightspace & $13 \%$ & $11 \%$ & $15 \%$ \\
\hline Moodle & $25 \%$ & $25 \%$ & $12 \%$ \\
\hline Sakai & $3 \%$ & $3 \%$ & $3 \%$ \\
\hline Homegrown LMS & $2 \%$ & $2 \%$ & $3 \%$ \\
\hline Others & $4 \%$ & $6 \%$ & $1 \%$ \\
\hline BNED LoudCloud Learning & $0 \%$ & $0 \%$ & $1 \%$ \\
\hline Blackboard ANGEL & $1 \%$ & $1 \%$ & $1 \%$ \\
\hline Pearson LearningStudio & $2 \%$ & $4 \%$ & $0 \%$ \\
\hline Schoology LMS & $1 \%$ & $0 \%$ & $0 \%$ \\
\hline
\end{tabular}

Tablo 1: ABD ve Kanada Yüksek Öğrenim Kurumları İçin ÖYS Pazar Payı (Hill, 2017)

Yaygın kullanılan öğrenme yönetim sistemleri incelendiğinde genel olarak aşağıdaki özelliklerden oluştuğu görülmektedir.

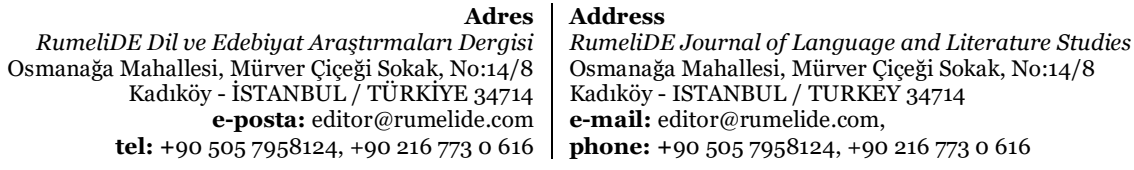


- Öğretmen/Öğrenci Yönetimi

- Kurs/Ders Yönetimi

- Sinıf Yönetimi

- Testler ve Ödevler

- Süreç/Illerleme Takibi

- İçerik Editörü

- Oyunlaştırma (Kısmen)

- Sertifikalandirma

- Sosyal Öğrenme Seçenekleri

- Etkileşimli Öğrenmeyi Destekleme

- E-Satış Eklentileri

- Bilgilendirme/Mesajlaşma Modülleri

- İçerik Kütüphanesi

- Notlar

- Tartışma/Forum

- Duyurular

- Takvim

Öğrenme yönetim sistemlerinin en önemli özelliklerinden biri de kullanıcılarına sunduğu içerik ve etkinlik türleridir. Bugün yaygın olarak kullanılan öğrenme yönetim sistemlerinden "Moodle"; sayısal cevap, metnin içine sürükle bırak, resmin üzerine sürükle bırak, açıklama, yazma, eşleştirme, gömülü yanıtlar, çoktan seçmeli, rastgele kısa cevaplı eşleştirme, eksik kelimeleri seçme, kısa cevap, doğru yanlış soru türlerinin kullanımına, "Blackboard" ise doğru yanlış, çoktan seçmeli, kısa yanıt, ya/ya da, yazma/açık uçlu soru türlerinin kullanımına imkân tanımaktadır.

Öğrenme yönetim sistemlerinin gerek yapısal ve yönetsel özellikleri gerek etkinlik ve soru türleri incelendiğinde yabancı dil öğretiminin ihtiyaçlarına; özellikle de okuma, dinleme, yazma, konuşma becerilerinin geliştirilmesine, kelime ve dil bilgisi öğretimine tam olarak hizmet edebilecek, dil öğretim sürecine yönelik raporlar sunacak özelliklere sahip olmadığı görülmektedir.

Yabancı dil öğretimi bilgi aktarımı ve bilginin ölçülmesinden çok bir beceri kazandırma süreci olduğu için ve bu sürecin her bir aşaması önem arz ettiği için mevcut öğrenme yönetim sistemlerinin geliştirilerek yabancı dil öğretimine hizmet edebilecek duruma dönüştürülmesine veya iyi bir yabancı dil öğrenme yönetim siteminin geliştirilmesine ihtiyaç duyulmaktadır. Böyle bir sistem tüm dillerin yabancı dil olarak öğretimine hizmet edebileceği gibi Türkçenin yabancı dil olarak öğretiminde de etkin bir şekilde kullanılabilecektir.

\section{Yabancı dil öğrenme yönetim sistemi (YDÖYS)}

Web teknolojilerinin, yapay zekânın, makine öğrenmesinin bugün geldiği nokta, yabancı dil öğrenen ve öğretenlerin ihtiyaçları, öğretimde kullanılabilecek içerik ve etkinlik türleri, öğrenme yönetim sisteminin eksiklikleri dikkate alındığında gelişmiş bir yabancı dil öğrenme yönetim sisteminin en az aşağıdaki 6 bileşenden ve alt başlıklarından oluşması gerektiği düşünülmektedir.

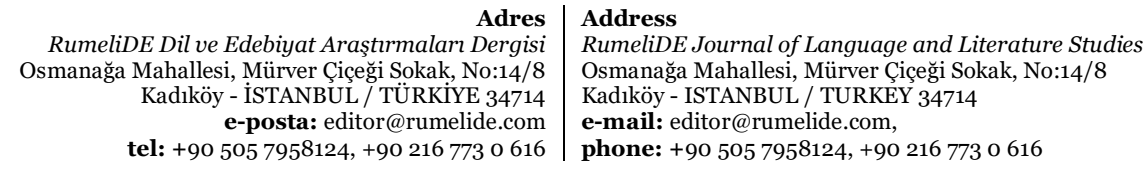




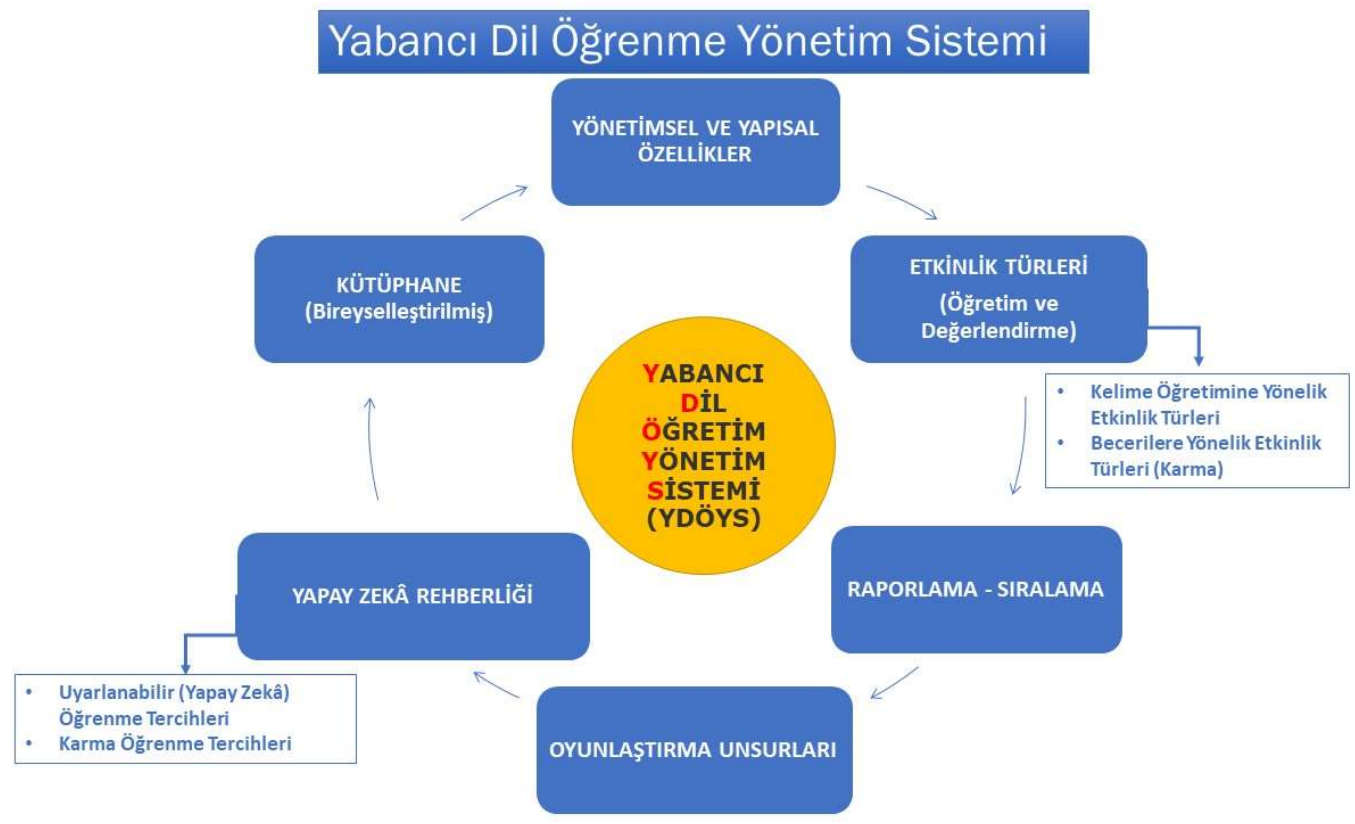

Şekil 2: Yabancı dil öğrenme yönetim sistemi bileşenleri

\section{Yönetimsel ve yapısal özellikler}

Bir yabancı dil öğrenme yönetim sisteminden gerek öğrenci merkezli gerek öğretmen merkezli gerek sistem (yapay zekâ) rehberliğinde öğretime; öğretim sürecinin tüm bileşenlerinin (kurum, yönetici, öğretmen, öğrenci, materyal) etkin bir şekilde yönetilebilmesine imkân vermesi; öğretim sürecinin detaylı bir şekilde raporlanması ve oyunlaştırma unsurlarının etkin bir şekilde kullanılabilmesi için gelişmiş öğretim içeriği standartlarından olan xAPI desteği özelliğine sahip olması olmazsa olmaz özelliklerdendir. Bu kapsamda YDÖYS’nde yönetimsel ve yapısal olarak aşağıdaki özelliklerin yer alması beklenmektedir.

- Öğrenci Merkezli Yapı (Öğrencinin kendi kendine (öğretmen desteği olmadan) öğrenebileceği bir yapı)

- Sistem Merkezli Yapı (Sistem yani yapay zekâ rehberliğinde öğrenmenin gerçekleşeceği bir yapı)

- Öğretmen Merkezli Yapı (Öğretmen rehberliğinde ödev-görev temelli öğrenmenin gerçekleşebileceği bir yapı)

- $\quad$ Öğretmen Hesapları

- Öğrenci Hesapları

- Detaylı Profil Olușturma (Veri analizleri ve uyarlanabilir öğrenme seçeneklerinde kullanılması için)

- $\quad$ Öğretmen / Öğrenci / Kurs / Ders / Ödev Atama ve İlişkilendirme Özellikleri

- Yaygın Web Araçları (H5P, Google Dokümanlar, Google Translate vb.) ile Entegrasyon.

- $\quad$ Alternatif Üyelik (giriş) Özellikleri (Google, Facebook vb. hesaplarla giriş)

- Kurs ve Derslerin Seviye ve Beceri Temelli Yapılandırılabilmesi

- $\quad$ Kurs, Müfredat, Ders, Etkinlikler Hiyerarşisi

- Sinav / Değerlendirme Araçları

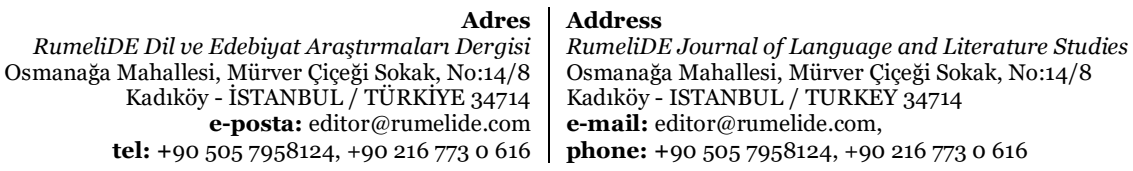


- Sertifikalandırma

- $\quad$ Forum / Yorum / Sosyalleşme araçları

- Kullanım Rehberi / Yönlendiriciler

- $\quad$ SCORM ve TinCan (xAPI) desteği

\section{Etkinlik türleri (Öğretim ve değerlendirme)}

YDÖYS’nde yaygın soru türlerinin (çoktan seçmeli, boşluk doldurma, doğru-yanlış, eşleştirme, açlk uçlu) yanı sıra özellikle kelime öğretimine ve becerilerin geliştirilmesine yönelik kullanılabilecek aşağıdaki soru/etkinlik türlerini içermesi beklenmektedir.

\subsection{Kelime öğretimine yönelik etkinlik türleri}

- Açıklamasından Kelimeyi Yazma

- Boşluk Doldurma (Seçmeli)

- Boşluk Doldurma (Yazmalı)

- $\quad$ Dinle ve Bul (Soru Sesli)

- Dinlediği Açılamayı Yazma

- Dinlediğini/Duyduğunu Yaz

- Doğrusunu Bul

- Eşleştirme (Metin/Resim/Ses)

- $\quad$ Kelime Kartı

- Resimdekini Yaz

- $\quad$ Kelimeyi Oku/Seslendir

- Doğru Sesi Bul (Seçenekler Sesli)

- $\quad$ Dinle Tekrar Et (Sesli)

\subsection{Becerilere yönelik etkinlik türleri (Karma)}

- $\quad$ Eşleştirme - Resim / Kelime / Ses

- Dinle ve Bul (Soru Sesli) - Resimden / Açıklamadan

- $\quad$ Sesi Bul (Seçenekler Sesli) - Resimden / Metinden

- Duyduğunu Yaz - Kelime / Cümle

- Duyduğunu Sirala - Kelime / Cümle

- Resimdekini Yaz (Alternatif Cevaplar)

- Açılama Metninden Kelime Yaz - Seçenekli / Seçeneksiz

- Açıklama Sesinden Kelime Yaz

- $\quad$ Dinle - Seslendir

- Oku - Seslendir

- $\quad$ İşaretle (Hot Spot) Sesli / Yazılı

- $\quad$ Sesli Soru - Sesli Yanıt / Seçmeli Yanıt

- $\quad$ Paragraf/Cümle (Metin) - Boşluk Doldurma - Çoktan Seçmeli / Yazmalı

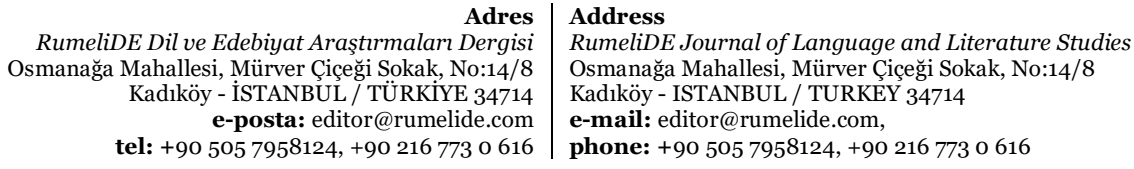


- Paragraf/Cümle (Dinleme) - Boşluk Doldurma - Çoktan Seçmeli / Yazmalı

- Kelime Siralama - Seçenekli/Seçeneksiz

- Cümle Suralama - Seçenekli/Seçeneksiz

- Doğru Yanlış - Resim/Ses/Kelime/Cümle

- Çoktan Seçmeli - Açıllama/Resim/Kelime/Ses

- Konuşma - Dallanma Senaryosu (Seçeneklerden Seslendirme)

- Yazma - Dallanma Senaryosu (Seçeneklerden)

- Dikte (Duyduğunu Yaz)

- Metni Sesli Oku (Sesin Metinsel Dökümü ve Aslı ile Karşılaştırma)

- Hafıza Kartı - Resim/Kelime/Ses

- Doğru Cevabı Seslendir

- Boşluk Doldurma Sesten - Yazmalı/Seçmeli

- Boşluk Doldurma - Yazmalı/Seçmeli

- Video İçi Sorular

- Bulmaca - Sesli/Resimli/Açıklamalı (Öğrenilen Kelimelere Göre Otomatik)

- Çeviri

Yukarıdaki etkinlik ve soru türlerine ek olarak aşağıdaki özelliklerin yer alması yabancı dil öğretimi sürecinde sistemin verimli bir şekilde kullanımına katkı sunacaktır.

- $\quad$ Etkinlik türleri -ihtiyaç duyulduğunda- araç dil kullanılabilecek şekilde yapılandırılmalıdır.

- Altyazılı ve altyazısız dinleme/izleme seçenekleri sunulmalıdır.

- Soruların cevaplanmasında metni göster/gizle seçenekleri sunulmalıdır.

- $\quad$ Dinleme ve izleme içeriklerinde dinleme/izleme sayısını belirleme, ileri veya geri alma izni verme/vermeme gibi yetkiler bulunmalıdır.

- Metinlerde gerekli görülen kelimelere ve cümlelere, sorulara ve seçeneklere açıklama, ipucu eklenebilmelidir.

\section{Raporlama - siralama}

Kendi kendine veya öğretmen destekli yabancı dil öğrenen bireylerin ve yabancı dil öğreten kurum ve öğretmenlerin ihtiyaç duyabileceği, süreci değerlendirebileceği çeşitli raporlara ihtiyaç duyulmaktadır. Bir yabancı dil öğrenme yönetim sistemi öğrenci, içerik ve zaman kullanımına yönelik karşılaştırmalı (seviye, beceri, yaş, ülke, süre vb.) ne kadar detaylı bilgi verebilirse dil öğretimine o kadar katkı sağlayacaktır.

Bir yabancı dil öğrenme yönetim sisteminin en azından aşağıdaki raporları sunması beklenmektedir.

- $\quad$ Seviye Temelli Raporlama

- Beceri Temelli Raporlama (Okuma, Dinleme, Yazma, Konuşma)

- $\quad$ Öğrenilen Kelimeler

- Uzun Süreli Hafızadaki Kelimeler

- Kısa Süreli Hafızadaki Kelimeler

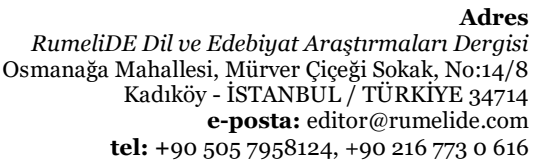

Address

RumeliDE Journal of Language and Literature Studies

Osmanağa Mahallesi, Mürver Çiçeği Sokak, No:14/8

Kadıköy - ISTANBUL / TURKEY 34714

e-mail: editor@rumelide.com

tel: +90 505 7958124, +90 2167730616 phone: +90 505 7958124, +902167730616 
- Grup ve Sinif Temelli Raporlama/Siralama

- Akran Temelli Raporlama/Siralama

- $\quad$ Ülke ve Bölge Temelli Siralama/Raporlama

- Günlük/Haftalık/Aylık Raporlama

- $\quad$ Dil Öğrenim Süreci Grafiği (Gelişim Grafiği)

$\mathrm{Bu}$ raporların profesyonel bir şekilde görselleştirilmesi ve kolay anlaşlır olması büyük önem arz etmektedir.

\section{Oyunlaştırma}

Oyunlaştırma; bireylerin motivasyonunu arttırarak sürece dâhil olma isteğini artıran, süreci çekici hale getiren uygulamalar ve oyun tasarım unsurlarının oyun bağlamı dışındaki durumlarda kullanılması (Bozkurt ve Genç-Kumtepen, 2014) şeklinde ifade edilmektedir. Oyunlaştırmanın en önemli özelliklerinden olan süreci çekici kılma, sürece dahil olma ve motivasyonu artırma yabancı dil öğretim sürecinde en çok ihtiyaç duyulan unsurlardandır. Ayrıca yabancı dil öğrenen bireyler aynı karakteristik özelliklere sahip olmadığı için oyunlaştırma unsurları bireyselleştirilebilir özelliklere de sahip olmalı, bireysel farklılıkları göz önünde bulundurmalıdır. Dolayısıyla oyunlaştırma unsurları yapılandırılırken Bartle (1996) veya Marczewski (2015) tarafindan ortaya konan oyuncu/kullanıcı türlerinin dikkate alınması fayda sağlayacak, oyunlaştırma unsurlarını güçlü hale getirecektir.

\section{Bartle'nin (1996) öne sürdüğü oyuncu türleri}

- Başaranlar

- Kaşifler

- Sosyalleşenler

- Katiller

\section{Marczewski’nin (2015) öne sürdügü oyuncu türleri}

- Sosyalleşenler

- Özgür Ruhlar

- Başaranlar

- Hayırseverler

- Oyuncular

- Düzen Bozucular

Oyuncu türlerine göre oyunlaştırma unsurlarının geliştirilmesi farklı oyuncu türlerinin sistemi kullanma oranını artıracak, öğrenme sürecine ciddi katkılar sağlayacak ve motivasyonu üst düzeyde tutacaktır. Dolayısıyla iyi bir yabancı dil öğrenme yönetim sisteminde oyuncu türleri dikkate alınarak aşağıdaki oyunlaştırma unsurlarının yer alması beklenmektedir.

\section{Oyunlaştırma unsurları}

- Avatarlar

- Hedefler

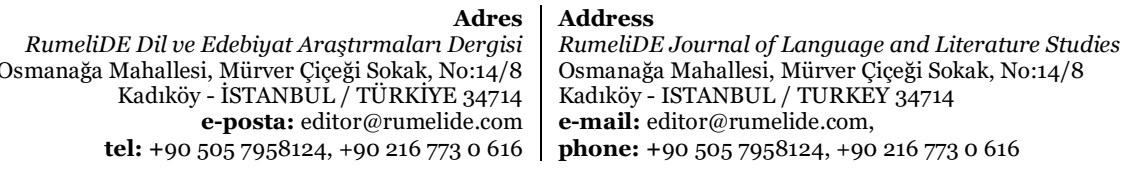


- Görevler

- Puanlar

- Rütbeler/Rozetler

- Seviyeler

- Siralamalar

- $\quad$ Liderler

- Gizemli Kutular

- Ödüller (Sanal)

○ -Sabit Ödüller

○ -Zamana Bağlı Ödüller

○ -Rastgele Ödüller

- İddialar

- Takımlar

- Yarışmalar

- Zorluklar (Nadir Hedefler)

- Sertifikalar

- Yardımseverlik/Dostluk/Destek

- Rastgele Oyun/Rakip/İçerik

- Meydan Okumalar

- Duygusal Mesaj ve Bildirimler

- Temalar (Farkl, Kişiselleştirilebilir)

- Sanal Para Kazanma Alanları (Zaman, Öğrenme, İlerleme, Yardım vb.)

- Sanal Para Kullanım Alanları (Avatar, İçerik, Tema, Oyunlar, Sosyalleşme vb.)

- Dil Öğrenme İkizi (Belli seviye ve durumlarda aynı öğrenme özelliklerine sahip kişileri bir araya getirme, karşlıklı onayla tanıştırma, yarıştırma)

\section{Yapay zekâ rehberliği}

Bugün geliştirilecek olan bir yabancı dil öğrenme yönetim sisteminin yapay zekâdan ve alt dallarından (makine öğrenmesi, derin öğrenme) faydalanmaması düşünülemez. Gerek içeriklerin gerekse içerikleri kullanan bireylerin analizinde yapay zekânın ve alt dallarının bugün bize sunduğu imkânlar dil öğretim sürecine, öğrencinin motivasyonuna, oyunlaştırma unsurlarının etkin ve verimli bir şekilde kullanılmasına, bireysel öğrenmeye ve motivasyona katkı sağlayacaktır. Yabancı dil öğrenme yönetim sistemine yapay zekânın entegre edilmesinin en önemli sebeplerinden biri de "uyarlanabilir öğrenme" ve "bireysel öğrenme" özelliklerinin öğretim sürecinde kullanılabilmesini kolaylaştırmasıdır.

Uyarlanabilir öğrenme: Uyarlanabilir öğretim olarak da bilinen uyarlanabilir öğrenme, öğrenenle etkileşimi düzenlemek ve her öğrencinin benzersiz ihtiyaçlarını karşılamak için özelleştirilmiş kaynaklar ve öğrenme etkinlikleri sunmak için bilgisayar algoritmalarını ve yapay zekâyı kullanan bir eğitim yöntemidir (Kaplan, 2021).

Bireyselleştirilmiş öğrenme (Keller Planı): 1963 yılında Fred Keller ve Gilmour Shermon tarafından ortaya konmuştur (Sevindik, 2010). Bu yöntemde öğretim sürecinde öğrenciler arasındaki

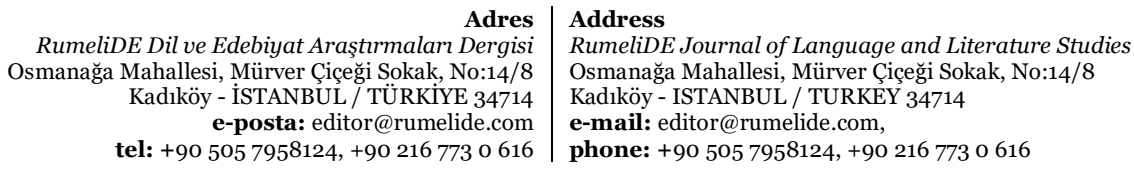


bireysel farklılıklar dikkate alınır. Her öğrencinin ilgi ve yetenekleri doğrultusunda araç gereç, yöntem ve teknikler kullanılır. Öğrencilerin öğrenme sürecine aktif katılımı ve kendi hızında öğrenmeleri sağlanmaya çalışılır. İngiliz eğitimci Dan Buckley (t.y.) bireyselleştirilmiş öğrenmeyi 2 başlık altında yeniden tanımlamıştır:

1. Öğretmenin öğrenmeyi uyarladığı "öğrenci için kişiselleştirme"

2. Öğrencinin kendi öğrenimini uyarladığı "öğrenci tarafindan kişiselleştirme"

YDÖYS'nde hem uyarlanabilir hem de kişiselleştirilebilir öğrenme modellerinin kullanılması söz konusudur.

Uyarlanabilir (Yapay Zekâ) öğrenme tercihleri: Bu modelde kişinin hangi zamanlarda, hangi içeriklerle, hangi etkinlik türleri ile daha iyi ve hızlı öğrendiği yapay zekâ tarafindan tespit edilir. Kişinin her bir etkileşimi onun bir sonraki adımını, karşılaşacağı içeriği, yöntemi vb. belirler. Kişinin etkileşimi ve sistemdeki süreci analiz için yeterli değilse benzer özeliklerdeki diğer öğrencilerin verileri kullanılarak bir program uygulanır. Bu yöntemde öğrencinin sistemi kullanımına yönelik analizler ön plandadır, bireysel tercihleri söz konusu değildir.

Karma öğrenme tercihleri: YDÖYS'nde kullanılacak olan bu yöntemde "Bireyselleştirilmiş Öğrenme" tercihleri bireye tamamen kendi planını oluşturacak şekilde sunulmaz. Bu yöntemde öğretmen tarafından (öğretmen merkezli yapı) veya yapay zekâ tarafından (sistem merkezli yapı, öğrenci merkezli yapı) kişiye uygun olarak belirlenen birden çok seçenek mevcuttur. Birey seçenekler arasından kendisi için uygun gördüğünü seçer.

Bir önceki yöntemde planlamayı tamamen yapay zekâ yaparken bu yöntemde yapay zekânın sunduğu seçenekler arasından birini tercih etme söz konusudur. Dolayısıyla bu yöntem karma yöntem olarak adlandırılmıştır.

Uyarlanabilir ve karma öğrenme modellerinde sistem kullanıcıya aşağıdaki başlıkları ve bu alandaki verileri dikkate alarak yönlendirmede bulunabilir.

- $\quad$ İçerik Türleri (Kişi hangi içerik türleri ile daha iyi öğreniyor?)

- Çalışma Zamanı (Kişi ne zaman daha iyi öğreniyor?)

- Çalışma Süresi (Kişinin aktif öğrenme süresi nedir?)

- $\quad$ Etkinlik Türleri (Kişi hangi etkinlik türleri ile daha iyi öğreniyor?)

- Beceri Türleri (Okuma, Dinleme, Yazma ve Konuşma becerilerinin tamamı için diğer tüm maddeler ayrıca değerlendirilir.)

- Hatırlatma Durumu/Zamanı/Yöntemi (Kişiye ne zaman, hangi yöntemle bildirimde bulunulmalı?)

- Konum Bilgisi (İşte, evde, seyahatte vb. hangi durumlarda öğrenme sürecinin nasıl gerçekleştiği analizi ve bu bilgilerin kullanılması)

- Kelime Öğrenme Yöntemi (Kelime öğreniminde hangi yöntem ve teknik daha çok ve kalıcı öğrenme sağliyor?)

- Kelime Yoğunluğu (Kişinin günlük kelime öğrenme ortalaması nedir?)

- Uzun Süreli Hafıza / Kısa Süreli Hafıza (Kişinin öğrendiklerinin kısa süreli hafıza veya uzun süreli hafızaya yerleşme durumlarının ve yöntemlerinin analizi ve bu bilgilerin kullanılması)

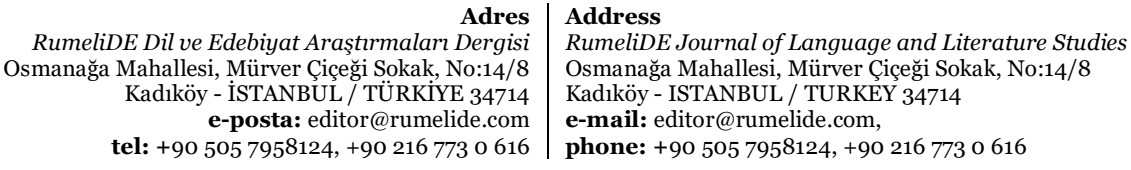


- Oyunlaştırma Unsurları (Hangi oyunlaştırma unsuru bireyin öğrenme sürecine daha fazla katkı sağlıyor?)

Bunlar ve bunlara benzer kişisel analizle ortaya çıan verilerin kullanılması yabancı dil öğretim sisteminin bireysel öğrenme konusunda bugünün ihtiyaçlarına ve bireylerine (dijital nesil) cevap verebilecek duruma gelmesini sağlayacaktır.

\section{Kütüphane (Bireyselleştirilmiş)}

Yabancı bir dili öğrenen bireylerin ihtiyaç duyacağı farklı içerik türlerinin yer aldı̆̆ı, dil öğrenenlerin belli kriterlere göre sıralama, sınıflandırma ve seçme şansının bulunduğu zengin bir kütüphane yabancı dil öğrenmekte olan bireylerin kendilerini geliştirmelerine yardımcı olacaktır. Burada yer alan içeriklerin tercih edilme ve kullanılma istatistikleri yine sistem tarafından analiz edilerek sistemin ve içeriklerin geliştirilmesi ve bireyselleştirilmiş öğrenmeye hizmet etmesi amacıyla kullanılabilecektir. Kütüphanede yer alan içeriklerden bazıları herkes için kullanıma açık olabileceği gibi bazıları ilgili kişinin seviyesi, puanı, ödülü vb. çerçevesinde sunulabilir veya oyunlaştırma unsuru olarak kullanılabilir.

Kütüphanede yer alacak tüm içerikler seviye, kelime sayısı, içerik türü, uzunluk vb. açıdan sınıflandırılabilir özelliklerde olmalıdır.

- Sözlükler (hazır ve/veya oluşturulabilir özellikte)

$\begin{array}{cl}\circ & \text { Resimli Sözlükler } \\ \circ & \text { Video Sözlükler } \\ \circ & \text { İki Dilli Sözlükler } \\ \circ & \text { Çok Dilli Sözlükler } \\ \circ & \text { Açılamalı sözlükler }\end{array}$

- Filmler

- Kisa Filmler

- Belgeseller

- Müzikler

- Metinler

- $\quad$ Sesli Metinler

- Sesli Kitaplar/Masallar/Hikâyeler/Tiyatrolar

- Haberler

- Radyolar

- TV Kanalları

- Çizgi Romanlar

- Oyunlar

- $\quad \ldots$

Altı başlık altında değerlendirilen yabancı dil öğrenme yönetim sisteminin günün ihtiyaçlarına ve yeni gelişmelere göre geliştirilebilir olması, farklı kurum veya kişiler tarafından kullanılabilir özellikte olması alandaki büyük bir boşluğun doldurulmasına vesile olacaktır. Böyle bir sistem geliştirilip açık kaynak

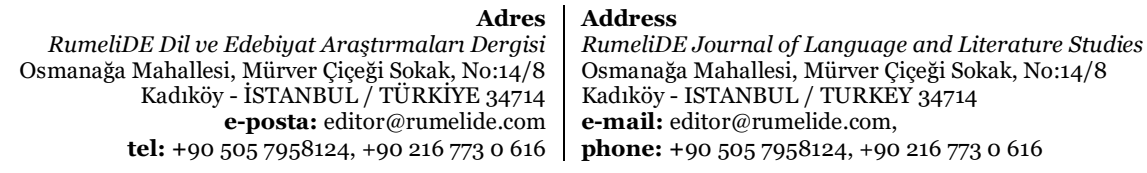


lisansıyla paylaşıldığı takdirde dünyadaki kullanımı yaygınlaşacak, hem tüm dillerin yabancı dil olarak öğretimine hem de çok kültürlülüğe hizmet edecektir.

\section{Sonuç ve öneriler}

Dünyada dil öğrenmeye ihtiyacın ve dil öğrenenlerin sayısının her geçen gün arttı̆̆ı görülmektedir. Bu artışla beraber yabancı dil öğrenenlerin her türlü öğrenme sürecini destekleyecek içeriklerin oluşturulabilmesi ve sunulabilmesi için gelişmiş bir öğrenme yönetim sistemine ihtiyaç duyulmaktadır.

Eğitim ve öğretim sürecini yönetebilmek amacıyla geliştirilen öğrenme yönetim sistemleri yabancı dil öğretim ve öğrenim sürecini tam olarak karşılayamamaktadırlar. Bu bağlamda çalışmada bahsedilen yabancı dil öğrenme yönetim sisteminin barındırması gereken özellikler ve bu özelliklere göre sunulan öneriler aşağıdaki gibi özetlenebilir:

- Geliştirilecek olan bir yabancı dil öğrenme yönetim sistemi yapı, etkinlik türleri, raporlama, oyunlaştırma, yapay zekâ rehberliği, kütüphane vb. bakımdan yabancı dil öğreten ve öğrenenlerin ihtiyaçlarına cevap verebilecek; özellikle okuma, dinleme, yazma, konuşma becerilerinin geliştirilmesine hizmet edebilecek özelliklere sahip olmalıdır.

- Yabancı dil öğrenme yönetim sistemi; çevrim içi, çevrim dışı, eş zamanlı, art zamanlı, sınıf içi ve sınıf dışı öğrenme ortamları dikkate alınarak geliştirilmeli ve kendi kendine öğrenme, sosyal öğrenme, bireysel öğrenme yöntemlerine hizmet edebilecek yapıda olmalıdır.

- Yabancı dil öğrenme yönetim sisteminin kişi ve kurumlar tarafından yaygın olarak kullanılabilmesi için bireysel ve kurumsal kullanımlara uygun bir yapıda olmalıdır.

- Yabancı dil öğrenme yönetim sistemi klasik etkinlik/soru türleri dışında yabancı dil becerilerini geliştirmeye yönelik etkinlik/soru türlerini de desteklemelidir.

- Yabancı dil öğrenme yönetim sistemi yaygın (SCORM) ve gelişmiş (xAPI) içerik standartlarını destekler özellikte olmalıdır.

- Yabancı dil öğretim merkezlerinin, kursların, TÖMER'lerin, yabancı dil öğreten bireylerin böyle bir sistemi kullanması teşvik edilerek kullanım esnasında eksik görülen, ihtiyaç duyulan özelliklere göre sistemin sürekli geliştirilmesi sağlanmalıdır.

- Tüm dillerin yabancı dil olarak öğretimine hizmet edebilecek bir alt yapıya sahip olacak olan yabancı dil öğrenme yönetim sisteminin açık kaynak olarak yayımlanması sağlanmalı ve/veya teşvik edilmelidir.

\section{Kaynakça}

Aslan, E. (2014). Yabancı dil öğretiminde robot öğretmenler. Ondokuz Mayıs Üniversitesi Eğitim Fakültesi Dergisi, 33 (1), 15-26. Erişim adresi https://dergipark.org.tr/tr/pub/omuefd/issue/20251/214861

Aslan, E. (2018). Otomatik çeviri araçlarının yabancı dil öğretiminde kullanımı: Google çeviri örneği. Selçuk Üniversitesi Edebiyat Fakültesi Dergisi, (39), 87-104. DOI: 10.21497/sefad.443355

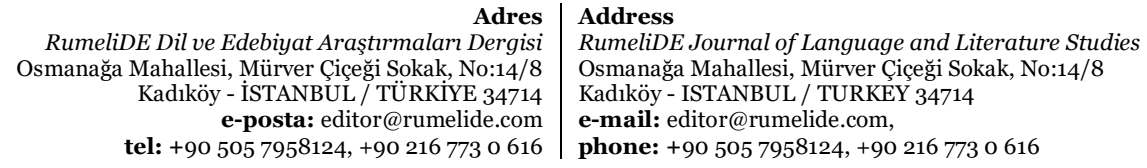


Avrupa İstatistik Ofisi. (2016). Foreign language skills statistics. Erişim adresi https://ec.europa.eu/eurostat/statisticsexplained/index.php?title=Foreign_language_skills_statistics.

Bartle, R. (1996). Hearts, clubs, diamonds, spades: Players who suit MUDs, Journal of MUD research (1:1), pp. 19-36.

Best Colleges. (2019). Online education trends report, Erişim adresi https://bit.ly/3lilvlK

Bırıncı, F. G. (2020). Yabancı dil olarak Türkçe öğretiminde kullanılan bilişim teknolojileri üzerine bir inceleme. Sakarya University Journal of Education, 10 (2), 350-371 . DOI: 10.19126/suje.685534

Bozavlı, E. (2017). Yabancı dilde öğrenenlerin sosyal medya aracıllğıyla sözel dil becerilerinin geliştirilmesine yönelik algıları. Insan ve Toplum Bilimleri Araştırmaları Dergisi, 6 (1), 627-640. Erişim adresi http://www.itobiad.com/tr/pub/issue/27443/292223

Bozavlı, E. (2017). Yeni teknolojiler ışığında eğitim aktörlerinin yabancı dil öğretiminde sanal sınıf algıları. Atatürk Üniversitesi Sosyal Bilimler Enstitüsü Dergisi, 21 (1), 347-358. Erişim adresi https://dergipark.org.tr/tr/pub/ataunisosbil/issue/35347/425798

Bozkurt, A. ve Genç-Kumtepe, E. (2014). Oyunlaştırma, oyun felsefesi ve eğitim: Gamification. Akademik Bilişim'de sunulan bildiri, Mersin Üniversitesi, http://ab.org.tr/ab14/bildiri/233.pdf Erişim Tarihi: 14.08.2021.

Bozna, H. (2019). İngilizceyi yabancı dil olarak öğrenenlerin etkileşimli e-destek ortamlarına yönelik algıları. Açıö̈̆retim Uygulamaları ve Araştırmaları Dergisi, 5 (1), 97-116. Erişim adresi https://dergipark.org.tr/tr/pub/auad/issue/44098/543496

Buckley, D. (t.y.). What is Personalised Learning? https://makeschoolpersonal.wordpress.com/whatis-personalised-learning/ Erişim Tarihi: 10.08.2021.

Çokyaman, M. \& Çelebi, M. (2021). Yabancı dil öğretiminde dijital hikâye anlatımının (DHA) akademik başarıya etkisi. Ahi Evran Üniversitesi Kirşehir Eğitim Fakültesi Dergisi, 22 (2), 994-1035. Erişim adresi https://dergipark.org.tr/tr/pub/kefad/issue/62829/993465

Demiral, H. \& Yavuz, Ş. (2016). Türkçenin yabancı dil olarak öğretiminde ders dışı öğrenme ortamları. Ĕ̆itim ve İnsani Bilimler Dergisi: Teori ve Uygulama, 7 (13), 129-146. Erişim adresi https://dergipark.org.tr/tr/pub/eibd/issue/29466/315930.

Erice, D. \& Ertaş, A. (2011). The impact of e-portfolio on foreign language writing skills. Ankara University Journal of Faculty of Educational Sciences (JFES), 44 (2), 73-94. DOI: 10.1501/Egifak_0000001225

Geçgel, H. \& Peker, B. (2020). Multimedya araçlarının yabancı dil öğretimine etkisi üzerine öğretmen görüşleri. RumeliDE Dil ve Edebiyat Araştırmaları Dergisi, (20), 12-22. DOI: 10.29000/rumelide.791070.

Göker, M. \& İnce, B. (2019). Web 2.0 araçlarının yabancı dil olarak Türkçe öğretiminde kullanımı ve akademik başarıya etkisi. Turkophone, 6 (1), 12-22. Erişim adresi https://dergipark.org.tr/tr/pub/turkophone/issue/44969/568798.

Hill, P. (2017). State of higher ed LMS market for US and Canada: Fall 2017 edition. Erişim adresi https://eliterate.us/state-higher-ed-lms-market-us-canada-fall-2017-edition/.

İnal, E. \& Arslanbaş, F. (2021). Türkçenin yabancı dil olarak uzaktan öğretiminde iletişim odaklı web 2.0 araçları ve uygulama örnekleri. Bayburt Eğitim Fakültesi Dergisi, Yabancı Dil Olarak Türkçe Öğretimi Özel Sayısı, 228-249. DOI: 10.35675/befdergi.850781.

İnal, E. (2020). Yabancı dil olarak Türkçe öğreticilerinin eğitim teknolojisi standartları ile ilgili öz yeterliklerinin incelenmesi. Turkophone, 7 (1), 37-54. Erişim adresi https://dergipark.org.tr/tr/pub/turkophone/issue/56326/778481.

Kaplan, A. (2021). Higher education at the crossroads of disruption, the university of the 21st century. Emeral Publishers.

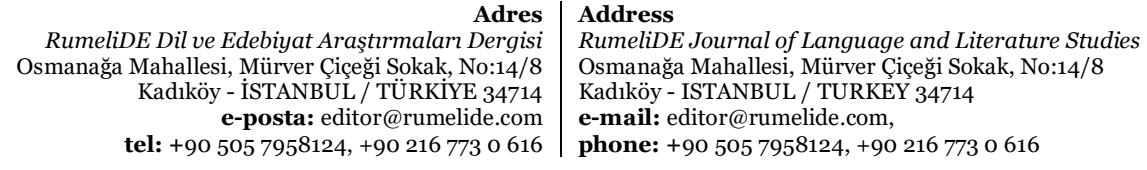


Karatay, H., Karabuğa, H. \& İpek, O. (2018). Türkçenin yabancı dil olarak öğretiminde Edmodo’nun kullanımı: Bir durum çalışması. Ana Dili Ĕ̆itimi Dergisi, 6 (4), 1064-1090. DOI: 10.16916/aded.452838.

Kaya, O. \& Tekiner Tolu, A. (2017). Yabancı dil öğretiminde (Almanca) dijital hikâye anlatım yönteminin araştırılması. Dil Dergisi, 168 (1), 5-20. DOI: 10.1501/Dilder_0ooooo0235.

Kazazoğlu, S. (2014). Yabancı dil öğretiminde teknoloji tabanlı etkileşim: Second life örneği. Dil Dergisi, (164), 39-51. DOI: 10.1501/Dilder_ooooooo210.

Kozikoğlu, A. G. İ. (2013). Yabancı dil öğretiminde bilgisayar kullanımına ilişkin öğretim elemanlarının görüşleri. Yüzüncü Yll Üniversitesi Eğitim Fakültesi Dergisi, 10 (1), 373-394. Erişim adresi https://dergipark.org.tr/tr/pub/yyuefd/issue/13705/165944.

Marczewski, A. (2015). User types. In even ninja monkeys like to play: Gamification, game thinking and motivational design (1st ed., pp. 65-80). CreateSpace Independent Publishing Platform.

Moralı, G. (2018). Yabancı dil olarak Türkçe öğretiminde blogların kullanımına yönelik kuramsal bir çalışma. Turkophone, 5 (1), 41-50. Erişim adresi https://dergipark.org.tr/tr/pub/turkophone/issue/36822/384598.

OECD, PISA 2018 Database, Table B.1. Erişim adresi https://webfs.oecd.org/pisa2018/foreignlanguages-and-careers.xlsx.

Özcan, Ş. \& Altıparmak, H. M. (2016). Türkçenin yabancı dil olarak öğretiminde temel yaşam alanlarından hareketle bilgisayar destekli bir kaynak önerisi: Görsel senaryo. Mustafa Kemal Üniversitesi Sosyal Bilimler Enstitüsü Dergisi, 13 (34), o-o. Erişim adresi https://dergipark.org.tr/tr/pub/mkusbed/issue/24545/259958.

Sarı, Y. E. (2018). Yabancı dil öğrenimi için teknolojiler: e-tandem ile yabancı dil öğrenimi. Diyalog Interkulturelle Zeitschrift Für Germanistik, 6 (2), 137-148. Erişim adresi https://dergipark.org.tr/tr/pub/diyalog/issue/42128/507210.

Sarıgül, K. (2021). Yabancı dil olarak Türkçe öğretiminde çevrim içi süreç değerlendirme araçları. Karamanoğlu Mehmetbey Üniversitesi Edebiyat Fakültesi Dergisi, 2021 Yunus Emre ve Türkçe Yılı Yabancı Dil Olarak Türkçe Öğretimi Özel Sayısı, 56-80. DOI: 10.47948/efad.922748.

Sevim, O., \& Kara, E. G. (2019). Türkçeyi yabancı dil olarak öğrenen sosyal medya kullanıcılarının okuma ve yazma kaygılarının çeşitli değişkenler açısından incelenmesi. EKEV Akademi Dergisi, (78), 449-466.

Sevindik T. (2010). Özel öğretim yöntemleri ders notları [PDF Dosyası]. Yıldız Teknik Üniversitesi Ĕ̆itim Fakültesi. Erişim adresi: https://alonot.com/wp-content/uploads/2019/o6/AnadoluA\%C3\%B6f-\%C3\%96zel-\%C3\%96gretim-Y\%C3\%B6ntemleri-Ders-Notlar\%C4\%B1.pdf

Sidney L. Pressey. (t.y.) Wikipedia içinde. Erişim adresi https://en.wikipedia.org/wiki/Sidney_L._Pressey.

Şahin, Y. (2010). Yabancı dil öğrenen öğrencilerin bilgisayardan yararlanmalarına ilişkin görüşleri. Erciyes Üniversitesi Sosyal Bilimler Enstitüsü Dergisi, 1 (29), 307-316. Erişim adresi https://dergipark.org.tr/tr/pub/erusosbilder/issue/23763/253297.

Taylan, U. (2018). Voscreen online foreign language learning environment. Journal of Educational Technology and Online Learning, 1 (1), 60-69. DOI: 10.31681/jetol.376754.

Türker, M. S. (2019). Blog kullanımının yabancı dil olarak Türkçe öğrenenlerin okumaya yönelik tutumları üzerindeki etkisi. Trakya Ĕ̆itim Dergisi, 9 (2), 199-210. DOI: 10.24315/tred.427539.

Ustabulut, M. Y. \& Keskin, S. (2020). Yabancı dil olarak Türkçe eğitimi alan uluslararası öğrencilerin öğrenme etkinliğini geliştirme amaçlı sosyal medya kullanım-doyum motivasyonları. Ondokuz Mayıs Üniversitesi Eğitim Fakültesi Dergisi, 39 (1), 155-173. Erişim adresi https://dergipark.org.tr/tr/pub/omuefd/issue/53755/657701.

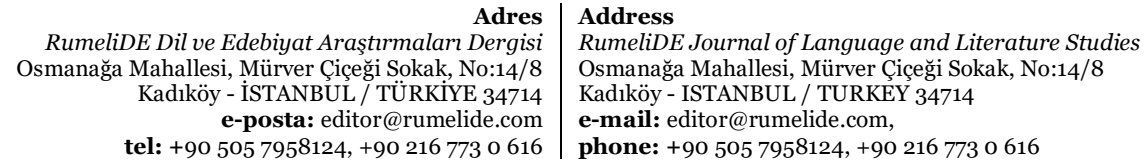


142 / RumeliDE Journal of Language and Literature Studies 2021.Ö10 (October)

Design proposal for a foreign language learning management system / K. Sarı̈ül (pp. 127-142)

Yaman, M. \& Bozdemir, O. (2010). Yabancı dil öğreniminde teknolojik yaklaşımlar. Atatürk Üniversitesi Kazım Karabekir Eğitim Fakültesi Dergisi, o (12), 219-235. Erişim adresi https://dergipark.org.tr/tr/pub/ataunikkefd/issue/2773/37129.

Zengin, Ö. \& Aksu, M. (2017). A review study on the integration of technology into foreign language education in Turkey. Ankara University Journal of Faculty of Educational Sciences (JFES), 50 (2), 79-104. DOI: 10.1501/Egifak_oooooo1398.

RumeliDE Dil ve Edebiyat Araşttrmaları Dergisi Osmanağa Mahallesi, Mürver Çiçeği Sokak, No:14/8 Kadıköy - İSTANBUL / TÜRKIYE 34714 e-posta: editor@rumelide.com tel: +90 $5057958124,+902167730616$
Address

RumeliDE Journal of Language and Literature Studies Osmanağa Mahallesi, Mürver Çiçeği Sokak, No:14/8

Kadıköy - ISTANBUL / TURKEY 34714

e-mail: editor@rumelide.com,

phone: +90 5057958124 , +90 2167730616 